\title{
A 600-year flood history in the Yangtze River drainage: Comparison between a subaqueous delta and historical records
}

\author{
WANG MinJie ${ }^{1,2}$, ZHENG HongBo $^{2 *}$, XIE Xin $^{1}$, FAN DaiDu $^{1}$, YANG ShouYe ${ }^{1}$, \\ ZHAO QuanHong ${ }^{1} \&$ WANG Ke ${ }^{1}$ \\ ${ }^{1}$ State Key Laboratory of Marine Geology, Tongji University, Shanghai 200092, China; \\ ${ }^{2}$ School of Earth Sciences and Engineering, Nanjing University, Nanjing 210093, China
}

Received April 7, 2010; accepted September 25, 2010

\begin{abstract}
Based on grain size analysis and high-resolution elemental scanning of core YD0901, taken from the subaqueous Yangtze River delta, a 600-year flood history was reconstructed for the Yangtze River drainage system. $\mathrm{Zr} / \mathrm{Rb}$ ratios were chosen as a proxy for Yangtze River floods. Zr resides mainly in the coarse-grained minerals, and Rb is found in the fine-grained minerals. When floods occur, the discharge of the Yangtze River increases, which carries more coarse-grained minerals into the East China Sea. Therefore, deposition of coarse-grained minerals significantly increases relative to fine-grained minerals on the subaqueous delta, and subsequently the $\mathrm{Zr} / \mathrm{Rb}$ ratios also increase. The higher the $\mathrm{Zr} / \mathrm{Rb}$ peaks, the greater number of coarse particles deposited by saltation processes. $\mathrm{Zr} / \mathrm{Rb}$ peaks correlate very well with historical records for Yangtze River floods. Especially at about AD 1870, the $\mathrm{Zr} / \mathrm{Rb}$ ratio reached a maximum value over the last 600 years, which is consistent with "the extreme flood event" in the upper and middle reaches of the Yangtze River in AD 1870, as indicated in the historical records. Results show that floods have occurred at a relatively high frequency over the last 600 years, which is consistent with historical records when, during the Ming-Qing Dynasty, floods occurred once every 4 years. In addition, spectral analysis of the $\mathrm{Zr} / \mathrm{Rb}$ ratio showed that there is close link between the Yangtze River floods and ENSO intensity.
\end{abstract}

Yangtze River floods, subaqueous Yangtze River delta, Zr/Rb ratio

Citation: Wang M J, Zheng H B, Xie X, et al. A 600-year flood history in the Yangtze River drainage: Comparison between a subaqueous delta and historical records. Chinese Sci Bull, 2011, 56: 188-195, doi: 10.1007/s11434-010-4212-2

As the main feature of global climate change, global warming has become an increasingly prominent issue, and is one of the most serious challenges facing sustainable development. With low-level circulation, global warming affects precipitation, and the occurrence of droughts and floods in large river basins. As China's longest river, the Yangtze plays a decisive role in China's social and economic development. However, the frequent occurrence of floods seriously affects economic development and the lives of people. The middle and lower reaches of the Yangtze River showed a clear warming trend in the 1990s. Meanwhile, precipitation also has increased significantly, which has resulted in

*Corresponding author (email: zhenghb@nju.edu.cn) an increasing probability of flooding [1]. Hence, it has become an important part of global climate change research to understand the modes and mechanisms of flooding to better predict future climate.

There usually are two ways to study paleofloods: compiling historical literature or investigating geological records. The first record of Yangtze River floods was 2000 years ago. Even so, early flood records before the Song Dynasty are scarce and lack continuity. The history of dynasties usually is intertwined with floods, droughts and wars [2]. Using geomorphology, sedimentology, archeology and other geological methods can provide longer time scales of flood records. The most common geological methods are to use the sedimentary records left by the floods to restore 
ancient flood frequency and intensity [3-7]. However, flood remains are vulnerable to post-scour and erosion, and thus only extreme floods are likely to leave sedimentary evidence. Therefore, it is difficult to achieve a high-resolution history of floods because of the lack of continuity. With regard to preservation of a good geological record, the subaqueous Yangtze River delta has many advantages over terrestrial flood sediments. For example, sedimentary environments in the delta are relatively stable, deposition rates are higher, and deposition processes are continuous. In addition, there are good dating materials (such as shells and foraminifera), which can be used readily to obtain accurate AMS ${ }^{14} \mathrm{C}$ ages. As the main deposition area of the Yangtze River since the Last Deglaciation, the subaqueous Yangtze River delta is likely to have nearly completely preserved the climate information for the entire Yangtze River basin during the Holocene, especially the extreme flood events. This paper reports results from core YD0901, taken from the subaqueous Yangtze River delta. Based on grain-size analysis and high-resolution elemental scanning, we attempted to recover a 600-year flood history of the Yangtze River, to build a long time scale of flood events in the Holocene.

\section{Materials and methods}

Most of the East China Sea continental shelf was exposed to land in the Last Glacial Maximum (LGM). During this time, the Yangtze River may have flowed into the sea through the western margin of the Okinawa Trough. With arrival of deglaciation, sea level rose rapidly, and the Yangtze River estuary gradually migrated inland. At about $7 \mathrm{ka} \mathrm{BP}$ (the Maximum Transgression), a huge estuary was formed in Zhenjiang and Yangzhou. Since then, the estuary has been filling because the sediment accumulation rate of the Yangtze River has been higher than the rate of sea level rise. These changes resulted in development of the present Yangtze River Delta [8] (Figure 1 (a)). The modern Yangtze delta system consists of two parts - the land delta plain and the subaqueous delta. In addition, it also includes the Fujian-Zhejiang mud belt, which formed from Yangtze River sediments. With hundreds of drill cores taken from the Yangtze River Delta Plain and Fujian-Zhejiang mud area, we have obtained a comprehensive, three-dimensional understanding of age and strata of the delta plain [9-14]. This framework has resulted in division of the Yangtze River Delta Plain into three basic stratigraphic parts, namely the main delta, northern and southern units [15]. In addition, the total deposition and deposition rate of the Holocene delta has been estimated [8]. Fujian-Zhejiang muddy sediments, which were formed during the Holocene, also were derived from the Yangtze River. In recent years, we have systematically studied the East China Sea Inner Shelf muddy sediments. Using stratigraphic data and shallow seismic methods, Liu et al. [16-18] estimated the total deposition of
Fujian-Zhejiang muddy sediments (Figure 1(a)). Wang et al. [11] found that the sedimentary environment of the $\mathrm{Fu}-$ jian-Zhejiang mud area has undergone three major changes in the type of environment since the Holocene transgression: near-shore environment, transitional environment and shallow marine environment. In contrast, there has been little research on the subaqueous Yangtze River delta. Research has been confounded by shallow drilling depths, inaccurate age sequences and low resolution [19-21]. In light of this deficiency, more studies have been supported in recent years to investigate surface deltaic sediments. For example, core YD0901 (31 $11^{\prime} 01.768^{\prime \prime} \mathrm{N}, 122^{\circ} 30^{\prime} 00.655^{\prime \prime} \mathrm{E}$, water depth of $21 \mathrm{~m}$, and length of $65.23 \mathrm{~m}$ ) of this study was obtained in the modern subaqueous delta of the Yangtze River in May 2009 by the State Key Laboratory of Marine Geology at Tongji University and the Zhejiang Geological Prospecting Bureau.

\subsection{Lithology and sedimentary facies}

Core YD0901 can be divided into three parts. The first and lowermost section, from 51.88-65.23 m, contains riverbed facies. During the Last Glacial Maximum (LGM), most of the East China Sea continental shelf was exposed to the land, and several paleochannels and giant incised valleys formed [22]. With the arrival of the last deglaciation, sea level rose gradually. Incised valleys began to fill with riverbed sediments [14]. The second part of the core, from 34.22-51.88 m, contains the submarine facies, and sea level achieved a maximum near $34.22 \mathrm{~m}$ when the transgression also reached its maximum [23]. This formed a great ancient estuary, the greatest landward extent of which was in Zhenjiang and Yangzhou [8]. The third and uppermost part of the core, from 0-34.22 m, contains the subaqueous delta facies. It represents a time when sea level reached its highest point, and the modern Yangtze River delta began to develop. Since then, the paleoestuary has gradually advanced to the position of the modern estuary, extending from Zhenjiang to Yangzhou.

\subsection{Age framework}

The age framework of core YD0901 is based on 8 shells that were subjected to AMS ${ }^{14} \mathrm{C}$ dating and corrected by Calib 5.0 software. The sediment above the top $5 \mathrm{~m}$, roughly corresponding to the Ming-Qing Dynasty, consists of silt $(75 \%-89 \%)$, clay $(10 \%-25 \%)$ and sand $(0-3.9 \%)$. According to an AMS ${ }^{14} \mathrm{C}$ age $(790 \pm 30$ a BP) at $4.01 \mathrm{~m}$, we established an age framework for the last 600 years, and a deposition rate of $0.92 \mathrm{~cm} / \mathrm{a}$.

\subsection{Laboratory measurements}

(i) XRF Core Scanner. The pretreatment was very simple and no disturbance to the core was caused by the scanning. 

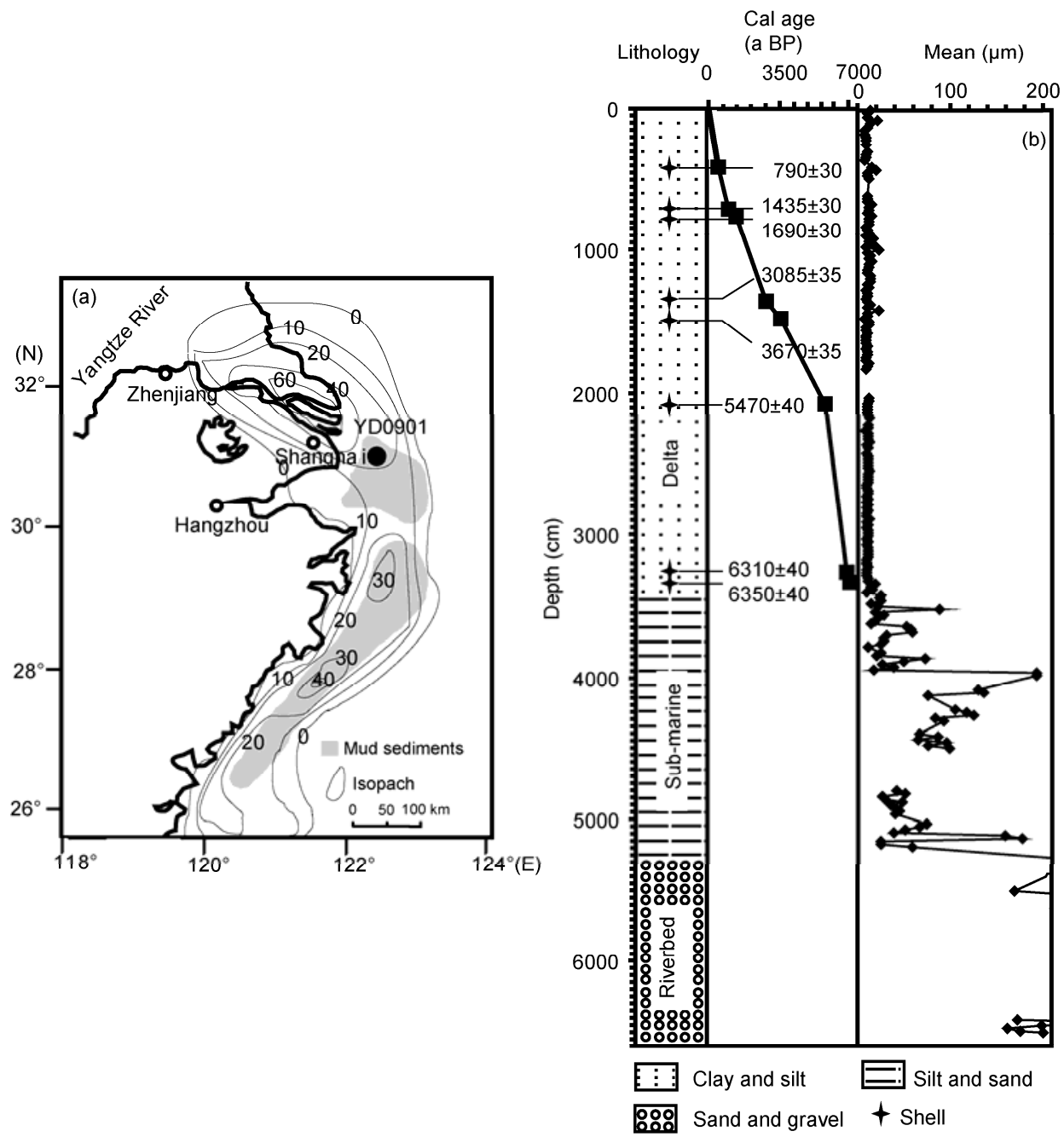

Figure 1 Study area and lithology. (a) Distribution and isopach map of the Yangtze River Delta, the subaqueous delta and Fujian-Zhejiang mud areas (modified from [18]); (b) core YD0901 lithology and AMS ${ }^{14} \mathrm{C}$ age control points.

More importantly, the resolution was very high, because the scanning interval was $1 \mathrm{~cm}$. Element compositions of Al-U could be obtained by this method.

(ii) Grain size analysis. The sampling interval was 10 $\mathrm{cm}$. Samples of $0.15 \mathrm{~g}$ were mixed with $10 \mathrm{~mL} 30 \%$ of $\mathrm{H}_{2} \mathrm{O}_{2}$ to remove organic matter. Then, $15 \mathrm{~mL} 25 \%$ acetic acid were added and boiled for 1 minute to remove carbonate. Finally, $300 \mathrm{mg}\left(\mathrm{NaPO}_{3}\right)_{6}$ were added, and ultrasonicated for 3 minutes. The samples were evaluated for grain size by a Beckman Coulter LS230 automatic laser particle size analyzer, the measurement range of which was $0.04-2000 \mu \mathrm{m}$, and the relative error was $\leqslant 1 \%$.

\section{Results}

\section{1 $\mathrm{Zr} / \mathrm{Rb}$ ratio as a proxy for floods}

In soil and sediments, $\mathrm{Zr}$ mainly is found in zircons [24]. During the weathering process, zircons maintain their original morphology, together with other stable minerals, such as quartz, both of which are enriched in the coarse particle component. Previous research has shown that $\mathrm{Zr}$ mainly is concentrated in the coarse fraction $(>20 \mu \mathrm{m})$ in Chinese Quaternary loess and lake sediments [25,26]. Moreover, isomorphic $\mathrm{Rb}$ is a typical dispersed element in nature. Thus, mostly isomorphic $\mathrm{Rb}$ is distributed in all kinds of rock-forming minerals, and seldom forms independent minerals $[27,28]$. As $\mathrm{Rb}$ and $\mathrm{K}$ have similar particle radii, potential and other geochemical parameters, $\mathrm{Rb}$ in all kinds of rocks mainly is dispersed in minerals containing $\mathrm{K}$, such as biotite, muscovite, feldspar and illite. During the weathering process, $\mathrm{Rb}$ tends to be enriched in clay minerals. Thus, $\mathrm{Zr} / \mathrm{Rb}$ ratios actually reflect the content of coarse minerals relative to clay minerals, and often the ratio is used as a winter monsoon proxy in Quaternary research [25].

Modern subaqueous delta sediments in the Yangtze River weather through long-distance transport and mixing. When floods occur, runoff and sediment discharge rapidly increases 
[29]. With the strong water force, a large number of coarse grained (Zr-rich) particles are carried into the sea by the Yangtze River. Because of backwater effects, grain saltation components mainly deposit near the mouth of the estuary, while grain components moved by rolling usually deposit on land. The fine grained suspended minerals (Rb-rich) tend to deposit in the prodelta, at a greater distance away from the estuarine mouth in comparison to the grains deposited by saltation, or jumping. This process leads to an overall increase in coarse grained minerals, found in core YD0901 at the delta front. Since fine grained minerals are reduced in this area, the $\mathrm{Zr} / \mathrm{Rb}$ ratio increases. Considering the scanning interval was $1 \mathrm{~cm}, \mathrm{Zr} / \mathrm{Rb}$ ratios can be used as a high-resolution subaqueous delta flood proxy, which is by far the highest resolution and most continuous proxy for the Yangtze River floods to date.

Figure 2 shows the curve of $\mathrm{Zr} / \mathrm{Rb}$ ratios for 600 years. It shows that most of the $\mathrm{Zr} / \mathrm{Rb}$ ratios are between 1.8 and 2.0, but sometimes there are dentate peaks, when
$\mathrm{Zr} / \mathrm{Rb}$ values can reach 3 or even higher. On the whole, $\mathrm{Zr} / \mathrm{Rb}$ peaks correspond very well to Yangtze River floods since AD 1840 as shown by Shi Yafeng [30]. For example at about $\mathrm{AD} 1870$, the $\mathrm{Zr} / \mathrm{Rb}$ ratio reached its maximum in the 600 year flood record, consistent with "the extreme flood event" recorded in the upper and middle reaches of the Yangtze River in AD 1870 [30,31]. Because of a lack of continuous and detailed flood records between AD 1350 and AD 1840, we only obtained flood-years from published literature and other terrestrial flood record sources [30,32-39]. It is not difficult to see that floods have been very frequent over the past 600 years, and are consistent with known frequent floods of the Ming-Qing Dynasty, where floods occurred once every 4 years [40]. In addition, the significantly high $\mathrm{Zr} / \mathrm{Rb}$ ratios correspond to historical flood years, which show that historical documents or land flood relics only recorded relatively large flood events. For small-scale flood events, the evidence was difficult to find because of post-erosion.

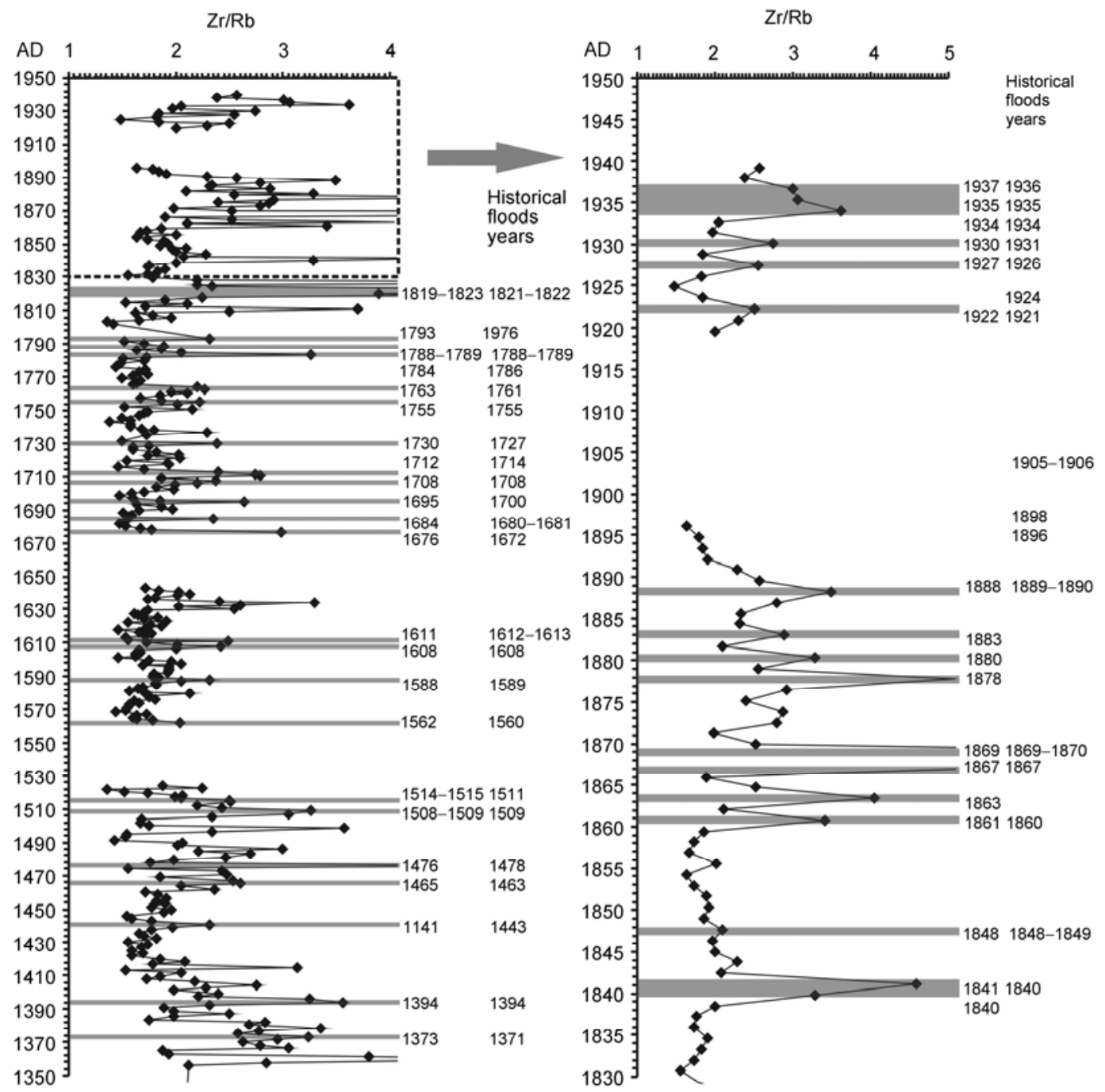

Figure 2 Comparison of flood records of core YD0901 and historical flood years between AD 1350 and AD 1950 [30,32-39]. 


\subsection{Grain size distribution of normal and flooding sediments}

As mentioned above, $\mathrm{Zr} / \mathrm{Rb}$ peaks correspond to flood sediments. Thus, it follows that the grain size distribution also should be consistent with flood features. In general, when floods occur, the water force becomes stronger and the Yangtze River may transport a large number of coarse sand particles into East China Sea. This would result in a significant increase of coarse grains in the subaqueous delta [41]. In addition, floods also can result in an increase in the mean size of lake sediments [42]. Thus, the grain size distribution is the most direct proxy for floods. By selecting some $\mathrm{Zr} / \mathrm{Rb}$ peak sections and a comparative normal section for grain size analyses, we found significant differences between the two grain size parameters (Table 1). Mean and median grain sizes were significantly coarser in relation to $\mathrm{Zr} / \mathrm{Rb}$ peaks, indicating the water force was stronger. This agrees with the presence of more coarse particles in the subaqueous delta when floods occur. In contrast, the grain size was fine in the normal section with respect to $\mathrm{Zr} / \mathrm{Rb}$ ratio, corresponding to non-flood periods.

Size frequency curves (Figure 3) show that flood and non-flood deposits have single peaks, indicating a single source of weathering for the vast Yangtze River basin. The frequency curves of floods are high and narrow, and the median or mean grain size is great. In contrast, the frequency curves of non-floods are low and wide, and the median or mean grain sizes are small. These results show that water force increases during floods, and the median grain size becomes coarser. As a result, the Yangtze River carries a large number of coarse grain sediments into the sea.

The cumulative probability curve can reflect the transport pathway of sediments, which is associated with the sedimentary environment. From Figure 3, we can see that the curve shows four or five-stages during individual flood periods, and a lack of roll components. In addition, the jumping components account for about 30\%-70\%, indicating strong water forces, which mainly reflect the short-distance transport characteristics of rapid torrents. In flood periods, the majority of the roll components would deposit on land and offshore, few of which could be incorporated into the subaqueous delta by the flood. Almost all the roll components in the subaqueous delta are incorporated by storms and waves [12]. In non-flood periods, the curve shows three-stages, which represent the typical fluvial deposition curve, with a lack of roll components, and instead showing suspended components of more than $90 \%$. This indicates that the sediments had experienced steady, long-distance, suspended, low-water energy depositional environments. Thus, the content of jumping components can be used to distinguish between floods and non-floods in the subaqueous delta. This indicates that the more jumping components there are, the stronger the water force.

\section{Discussion}

When floods occur, Yangtze River runoff and the flow rate increase. This results in an increase in terrestrial weathering materials to the East China Sea. In these circumstances, the coarse components of the subaqueous delta will increase. In addition, fine-grained components are driven by the flood to more distant off shore areas. This dynamic results in an increase in the coarse content relative to the fine particles within the delta. Thus, $\mathrm{Zr} / \mathrm{Rb}$ ratios increase during flooding. Further particle size analyses have shown that there are more jumping components during floods.

$\mathrm{Zr} / \mathrm{Rb}$ peaks correspond very well to the Yangtze River floods since AD 1840 shown by Shi et al. [30]. It is clear that floods have been very frequent since AD 1840. During this time, floods occurred 2 or 3 times every 10 years. However, there are historical flood records that do not correspond to our data. Possible reasons for these discrepancies may be that the historical flood years have been omitted, or the scales of floods were so small that they were not reported in the flood literature. Because of the lack of continuous and detailed flood records between AD 1350 and AD1840, we could only obtain flood-years from the literature and other terrestrial flood records [30,32-39]. Figure 2 shows strong correspondence in these records.

Table 1 Comparison of floods and non-floods with grain size parameters

\begin{tabular}{|c|c|c|c|c|c|c|}
\hline & Depth (m) & Mean $(\mu \mathrm{m})$ & $\operatorname{Median}(\mu \mathrm{m})$ & $\sigma$ & $\mathrm{S}$ & $\mathrm{K}$ \\
\hline \multirow{2}{*}{ Floods } & 0.71 & 22.10 & 19.13 & 1.90 & -0.60 & 1.81 \\
\hline & 4.05 & 14.96 & 12.94 & 1.59 & 0.01 & 2.28 \\
\hline \multirow[b]{2}{*}{ No floods } & 1.19 & 10.24 & 6.78 & 1.61 & 0.78 & 2.61 \\
\hline & 1.67 & 8.27 & 5.63 & 1.59 & 1.12 & 2.78 \\
\hline
\end{tabular}



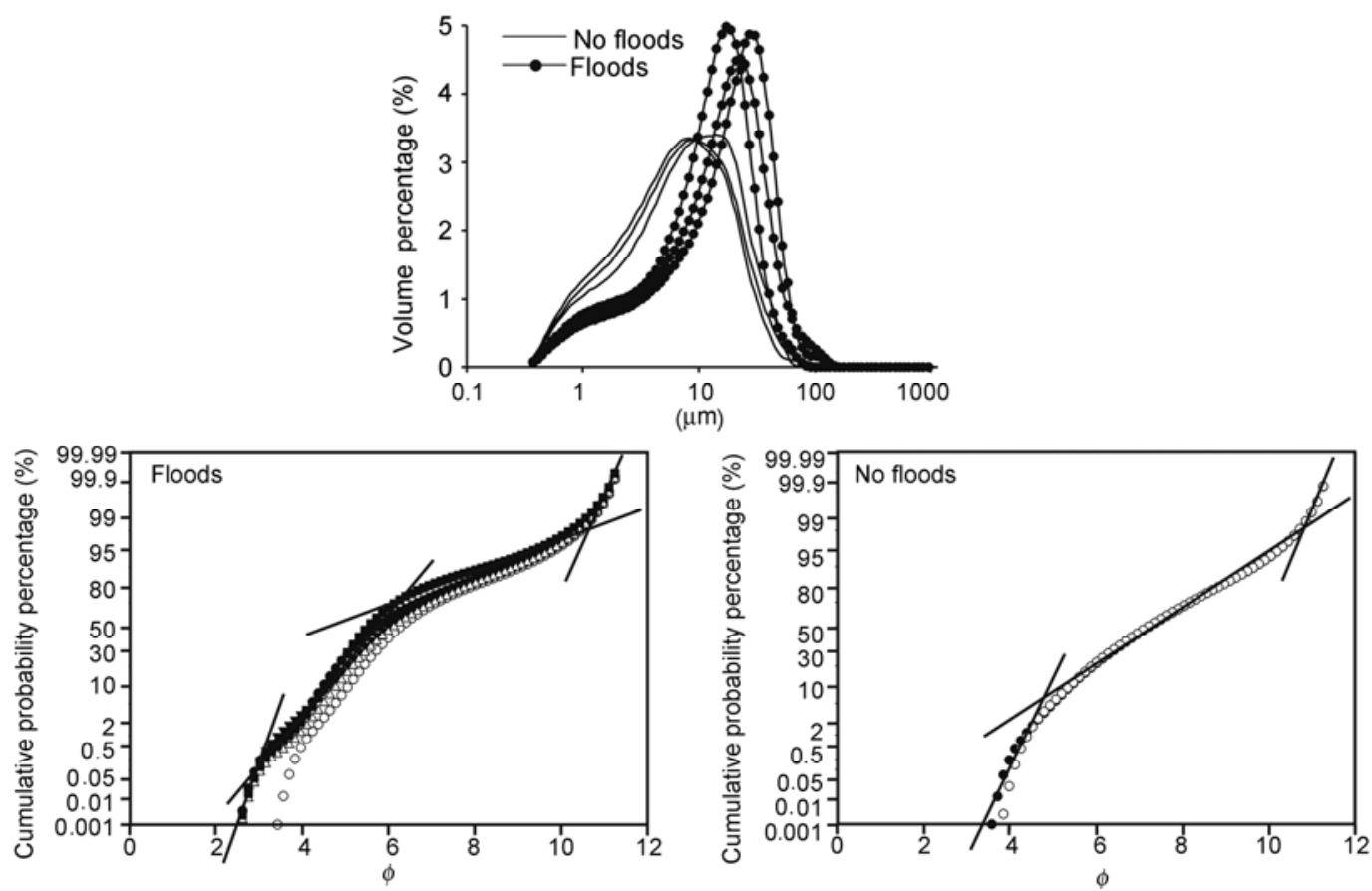

Figure 3 Comparison of floods and non-floods in the grain size frequency curves and cumulative normal probability curves.

Overall, historical flood years correspond to the $\mathrm{Zr} / \mathrm{Rb}$ "higher values" between 1350 and 1840, which fully supports the notion that historical documents or land flood relics only record relatively large flood events. For small-scale flood events, flood evidence does not preserve well because of post-erosion and scouring. As the final deposition center of terrestrial materials, the subaqueous Yangtze River delta has nearly continuously and completely recorded flood events for the entire Yangtze River basin for the Holocene, which cannot be recorded in land flood areas and historical documents.

With regard to the weather factors that may cause flooding, many researchers believe that there may be some link with ENSO on a short time-scale [43-46].
ENSO events result in abundant rain, which may cause flooding. From $\mathrm{Zr} / \mathrm{Rb}$ ratio spectral analysis for the last 600 years (using software Redfit35 [47] (Figure 4)), with a $95 \%$ confidence level test, it is possible to detect the following cycles: 6.9, 5.2, 4.7, 4.5 a and 3.9 a, which coincide with modern ENSO cycles (3-8 a) [48]. This suggests that the Yangtze River flood events may indeed be correlated with low-latitude ocean-atmosphere activity.

\section{Conclusions}

Through grain size analysis and high-resolution elemental scanning of core $\mathrm{YD} 0901$, we chose $\mathrm{Zr} / \mathrm{Rb}$ ratios as proxies

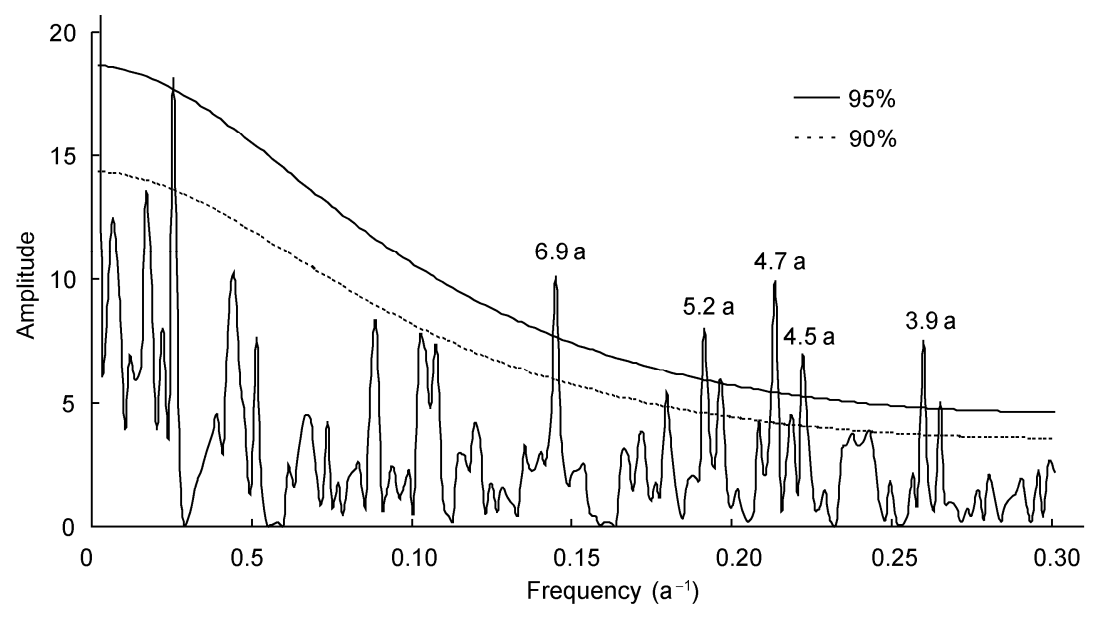

Figure $4 \mathrm{Zr} / \mathrm{Rb}$ ratio spectral analysis of core YD0901 for the past 600 years. 
for Yangtze River floods. $\mathrm{Zr} / \mathrm{Rb}$ peaks corresponded to the flood deposits. The trends indicated that the higher the $\mathrm{Zr} / \mathrm{Rb}$ peaks, the more coarse particles and jumping components were observed in the sediments. $\mathrm{Zr} / \mathrm{Rb}$ peaks corresponded very well to Yangtze River floods. For example, at about $\mathrm{AD} 1870$ (an extreme flood event), the $\mathrm{Zr} / \mathrm{Rb}$ ratio also was at its maximum value for the last 600 years. Because of a lack of continuous and detailed flood records between AD 1350 and AD1840, we only obtained floodyears from the literature and other terrestrial flood record sources. It is clear that floods have been very frequent for the last 600 years, which is consistent with historical records indicating that the Ming-Qing Dynasty was a period of severe flooding (a recurrence interval of once every 4 years). $\mathrm{Zr} / \mathrm{Rb}$ ratio spectral analyses indicated there may be links between Yangtze River floods and ENSO events. The present study provides a method to study high-resolution flooding history in the Yangtze River drainage for the Holocene.

1 Jiang T, Shi Y F. Global climatic warming, the Yangtze floods and potential loss (in Chinese). Adv Earth Sci, 2003, 18: 277-284

2 Huang Z S. The historical flood and drought in Yangtze River basin (in Chinese). Yangtze River, 2003, 34: 1-3

3 Yang D Y, Xie R B. Paleoflood lack-Water Deposits (in Chinese). Acta Sedimentol Sin, 1997, 15: 29-32

4 Bai J J, Zou H X, Zhu C. Archaeological discovery and research on the remains of the paleoflood of the Yuxi site. Chinese Sci Bull, 2008, (Suppl I): 18-27

5 Zhu C, Zheng C G, Ma C M, et al. The study on ancient flood sediment at central dam ruins in the reservoir area of Three Gorges of the Yangtze River (in Chinese). Chinese Sci Bull, 2005, 50: 2240-2250

6 Zhang Y F, Li C A, Chen L, et al. Magnetic fabric of Holocene palaeo-floods events in Jianghan Plain (in Chinese). Earth Sci-J Chi Univ Geosci, 2009, 34: 985-992

7 Zhao J B, Zhou X H, Sun G Z. Research on flood change indicated by deposit in high valley flat profile of Weihe River in Xianyang (in Chinese). Acta Sedimentol Sin, 2007, 25: 597-602

8 Li B H, Li C X, Shen H T. A preliminary study on sediment flux in the Changjiang delta during the postglacial period. Sci China Ser D-Earth Sci, 2003, 46: 743-752

9 Li C X, Chen Q Q, Zhang J Q, et al. Stratigraphy and paleoenvironmental changes in the Yangtze Delta during the Late Quaternary. J Asian Earth Sci, 2000, 18: 453-469

10 Li C X, Wang P, Sun H P, et al. Late Quaternary incised-valley fill of the Yangtze delta (China): Its stratigraphic framework and evolution. Sed Geol, 2002, 152: 133-158

11 Wang K, Zheng H B, Maarten P, et al. High-resolution paleoenvironmental record of the mud sediments of the East China Sea Inner Shelf (in Chinese). Mar Geol Quat Geol, 2008, 28: 1-10

12 Xiao S B, Li A C, Jiang F Q, et al. Recent 2000-year geological records of mud in the inner shelf of the East China Sea and their climatic implications. Chinese Sci Bull, 2005, 50: 466-471

13 Xiao S B, Li A C, Chen M H, et al. Recent 8 ka mud records of the East Asian winter monsoon from the inner shelf of the East China Sea (in Chinese). Earth Sci-J Chi Univ Geosci, 2004, 49: 2233-2238

14 Li C X, Fan D D. Development of the Holocene Changjiang delta and its influence on adjacent coastal sedimentary systems (in Chinese). J Palaeogeogr, 2009, 11: 115-122

15 Li C X, Fan D D, Zhang J Q. Late Quaternary stratigraphical frame- work and potential environmental problems in the Yangtze Delta area (in Chinese). Mar Geol Quat Geol, 2000, 20: 1-7

16 Chen Z Y, Saito Y, Kanai Y, et al. Low heavy metal concentration in the Yangtze estuarine sediment, China: A diluting setting. Estua Coast Shelf Sci, 2004, 60: 91-100

17 Chen Z Y, Stanley D J. Yangtze delta, eastern China: 2. Late Quaternary subsidence and deformation. Mar Geol, 1993, 112: 13-21

18 Liu J P, Xu K H, Li A C, et a1. Flux and fate of Yangtze River sediment delivered to the East China Sea. Geomorphology, 2007, 85: 208-224

19 Tang B G, Zhan Y P. Stratigraphic division of cores from shallow holes in Changjiang River subaqueous delta (in Chinese). Mar Geol Quat Geol, 1986, 6: 41-52

20 Qin Y S, Zhao Y Y, Chen L R, et al. Geology of the East China Sea (in Chinese). Beijing: Science Press, 1987. 100-136

21 Wang Z Y, Saito Y, Hori K, et al. Yangtze offshore, China: Highly laminated sediments from the transition zone between subaqueous delta and the continental shelf. Estua Coast Shelf Sci, 2005, 62: $161-168$

22 Li C X, Fan D D, Yang S Y, et al. Characteristics and formation of the Late Quaternary incised-valley sequences in estuary and delta areas in China (in Chinese). J Palaeogeogr, 2008, 10: 87-97

23 Li C X, Wang P X. Research of the Late Quaternary Stratigraphy of the Changjiang Estuary (in Chinese). Beijing: Science Press, 1998. 114-172

24 Chen J, An Z S, John H. Variation of $\mathrm{Rb} / \mathrm{Sr}$ ratios in the loess-paleosol sequences of central China during the last 130000 years and their implications for monsoon paleoclimatology. Quat Res, 1999, 51: 215-219

25 Liu L W, Chen J, Chen Y, et al. Variation of $\mathrm{Zr} / \mathrm{Rb}$ ratios on the Loess Plateau of central China during the last $130 \mathrm{ka}$ and its implications for winter monsoon. Chinese Sci Bull, 2002, 47: 1298-1302

26 Chen S Y, Wang S M, Jin Z D, et al. Variation of $\mathrm{Zr} / \mathrm{Rb}$ ratios in lacustrine sediments of the central Tibetan Plateau and its environment implications (in Chinese). Mar Geol Quat Geol, 2003, 23: 35-38

27 Wang S H, Zhang G D, Zhang J S, et al. Geochemical Studies on Rb and $\mathrm{Sr}$ in the Mud on the Inner Shelf of the East China Sea and Their Palaeoclimate Significance (in Chinese). Sci Technol Rev, 2007, 25: 22-27

28 Chen J, Qiu G, Lu H Y, et al. The geochemical evidence of $\mathrm{Rb}$ and $\mathrm{Sr}$ for the changes of summer monsoon in Loess Plateau in the recent $130 \mathrm{ka}$ (in Chinese). Chinese Sci Bull, 1996, 41: 1963-1966

29 Fan D J, Qi H Y, Sun X X, et al. A new method to evaluating sedimentary rate on the Yangtze River subaqueous delta: Seasonal Sedimentary Record of Bio-Si (in Chinese). Per Ocean Univ Chi, 2009, 39: $1025-1028$

30 Shi Y F, Jiang T, Su B D, et al. Preliminary analysis on the relation between the evolution of heavy floods in the Yangtze River Catchment and the climate changes since 1840 (in Chinese). J Lake Sci, 2004, 16: 289-297

31 Ge Z S, Yang D Y, Li X S, et al. The paleoflooding record along the up reaches of the Changiiang River since the Late Pleistocene epoch (in Chinese). Quat Sci, 2004, 24: 555-560

32 Zhu C, Yu S Y, Lu C C. The study of Holocene environmental archaeology and extreme flood disaster in the Three Gorges of the Changjiang River and the Jianghan Plain (in Chinese). Acta Geogr Sin, 1997, 52: 268-278

33 Qiao S X, Chen Z H. The analysis of historical carved stone flood record of Chuanjiang (in Chinese). Meteorol J Hubei, 1999, 1: 4-7

34 Tian X S, Z C, Yin Q, et al. Grain Size Characteristics of Flood Sedimentary Environment in Zhongba Site, the Three Gorges Reservoir, Changjiang River (in Chinese). Acta Sedimentol Sin, 2007, 25: 261-266

35 Wu Q L, Zhang P Z, Zhang H P, et al. A palaeo-earthquake induced damming and bursting of Yellow River and the abnormal flood that destroyed Lajia relic (in Chinese). Sci China Ser D-Earth Sci, 2009, 39: 1148-1159

36 Zhao H X, Zheng J Y, Ge Q S. The reconstruction of 1755 and 1849 severe flood events in Jiangsu and Anhui provinces (in Chinese). Sci 
Meteorol Sin, 2004, 24: 460-467

37 Yi C L, Liu H F, Rose N L, et al. Sediment sources and the flood record from Wanghu Lake, in the middle reaches of the Yangtze River. J Hydrol, 2006, 329: 568-576

38 He H C, Wang Y, Li S H. Tracing flood water level along Nanjing cliff bank of the Yangtze River (in Chinese). Acta Geogr Sin, 2004, 59: 938-947

39 Xie Y Y, Li C A, Wang Q L, et al. Sedimentary records of paleoflood events during the last 3000 years in Jianghan Plain (in Chinese). Sci Geogr Sin, 2007, 27: 81-84

40 Liu P L. The cyclic Geography study on the historical floods in the Yangtze River (in Chinese). Adv Earth Sci, 2000, 15: 503-508

41 Brown S L, Bierman P R, Andrea L, et al. $10000 \mathrm{yr}$ record of extreme hydrologic events. Geology, 2000, 28: 335-338

42 Shi X L, Qin B Q. Grain-size characteristic and their environmental significance of Wanghu Lake sediments in the middle reaches of Yangtze River (in Chinese). Mar Geol Quat Geol, 2009, 29: 117-122
43 Tang Y M, Guo L. Research on drought/flood influence factors in China (in Chinese). Sci Geogr Sin, 1990, 1: 77-84

44 Zhang L P. El Nino events and its influences on West Pacific subtropical high and flood in Yangtze River basin (in Chinese). Explor nat, 1999, 18: 86-90

45 Jiang T, Zhang Q, Zhu D M, et al. Yangtze floods and droughts (China) and teleconnections with ENSO activities (1470-2003). Quat Int, 2006, 144: 29-37

46 Yu F L, Chen Z Y, Ren X Y, et al. Analysis of historical floods on the Yangtze River, China: Characteristics and explanations. Geomorphology, 2009, 113: 210-216

47 Schul Z M, Mudelseem M. REDFIT: Estimating red-noise spectra directly from unevenly spaced paleoclimatic time series. Comput Geosci, 2002, 28: 421-426

48 Peng Z, Chen T, Nie B, et al. Coral $\delta^{18} \mathrm{O}$ records as an indicator of winter monsoon intensity in the South China Sea. Quat Res, 2003, 59: $285-292$

Open Access This article is distributed under the terms of the Creative Commons Attribution License which permits any use, distribution, and reproduction in any medium, provided the original author(s) and source are credited. 